\section{The learnability level of rhythm named "zencîr usûlü" with Dalcroze teaching method in Turkish music rhythm education}

\section{Türk mûsıkîsi usûl eğitiminde Dalcroze öğretim yöntemi ile zencîr usûlünün öğrenilebilirlik düzeyi}

\author{
Sedat Tamay ${ }^{1}$ \\ Nuray Dönmez Devecioğlu ${ }^{2}$
}

\begin{abstract}
In this study, by using the Dalcroze teaching method in the education of special talented students, practices focused on the perception of the Turkish musical "zencîr usûlü" with the support of the musical element and the determination of the level of learnability. However, with the applied curriculum, it is aimed to develop rhythmic perception and musical sensitivity by using interdisciplinary method technique and Dalcroze teaching method technique.

The subject study group of the study was formed from the students of the music department studying in Akhisar Science and Art Center affiliated to the Ministry of National Education. In this study; A curriculum suitable for students' levels was prepared by foreseeing that gifted students grasped and progressed in a process three times faster than their peers, and that many activities would be easier for them than their peers. Based on the saying "Body movement with music is one, it cannot be separated" mentioned in Ancient Greece, the evaluation of the teaching technique we
\end{abstract}

\section{Özet}

Bu çalışmada, özel yetenekli öğrenci eğitiminde Dalcroze öğretim yöntemi kullanılarak, Türk mûsıkîsi zencîr usûlünün müzik unsuru ile desteklenerek algılanması ve öğrenilebilirlik düzeyinin tespiti üzerinde yoğunlaşılan uygulamalar yapılmıştır. Bununla birlikte, uygulanan öğretim programıyla disiplinleraras1 yöntem tekniği ve Dalcroze öğretim yöntem tekniği kullanılarak ritmik alg1 ve müzikal duyarlılığın geliştirilmesi amaçlanmıştır.

Araştırmanın denek çalışma grubu, Milli Eğitim Bakanlığına bağlı Akhisar Bilim ve Sanat Merkezinde öğrenim gören müzik bölümü öğrencilerinden oluşturulmuştur. $\mathrm{Bu}$ araştırmada; özel yetenekli öğrencilerin, yaşıtlarına göre normalden üç kat daha hızlı bir süreçte konuyu kavradıkları ve ilerledikleri, yaşıtlarına göre pek çok etkinliğin onlara daha kolay gelebileceği ön görülerek öğrencilerin seviyelerine uygun bir öğretim program1 hazırlanmıştır. Antik Yunan'da zikredilen "Müzikle beden hareketi birdir, ayrılamaz" sözünden yola çıarak, Türk mûsıkîsi usûl icra tekniği (meşk sistemi) ile öngördüğümüz

\footnotetext{
1 Dr. Öğr. Üyesi, Ardahan Üniversitesi, Güzel Sanatlar Fakültesi, Türk Müziği Bölümü, sedattamay@ardahan.edu.tr

(iD) Orcid ID: $0000-0003-1797-5210$

2 M.A., M.E.B., nuraydonmez83@icloud.com (D) Orcid ID: 0000-0003-4465-4404
} 
Tamay, S., \& Dönmez Devecioğlu, N. (2021). Türk mûsıkîsi usûl eğitiminde Dalcroze öğretim yöntemi ile zencîr usûlünün ögrenilebilirlik düzeyi. Journal of Human Sciences, 18 (2), 215-232. doi: 10.14687/ihs.v18i2.6101

envisioned with the Turkish musical procedural technique, the pre-test post-test experimental design with control group Handled using. In order to determine whether there is a significant difference between test results, Mann - Whitney U Test, and "SPSS 20" package program was used for pre-test and post-test results. In order to determine the reliability of the study, an expert opinion form regarding the rubric and rubric was used at the pre-test and post-test stages. In the control group, the lessons were taught with the traditional teaching system, while in the experimental group, the teaching model was handled. According to the findings obtained in the study, it was determined that the experimental group in which the teaching model based strategies were applied was more successful than the control group in which the traditional method technique was used.

Keywords: Education, Music, Dalcroze teaching method, Turkish music, rhythm (zencir usûlü).

(Extended English summary is at the end of this document)

\section{GİRIŞ̧}

İnsanlık tarihi günbegün yükselen ve her yeni bir günde biriktirilen kazanımların deneyimlenmesi üzerine şekil almaktadır. Müzik, insanlık tarihine eşlik eden, toplumların gelişimi ile sürekli olarak değişiklik gösteren, niteliksel ve niceliksel yönüyle çok disiplinli bir karaktere sahiptir. $\mathrm{Bu}$ araştırmada özel yetenekli öğrenci eğitiminde, Dalcroze öğretim yöntemi ile Türk mûsıkîsi zencîr usûlünün müziksel algılanması ve öğrenilmesi için disiplinler arası yöntem tekniği kullanılmıştır. Uygulanan plan ve program, ezberlemenin ötesinde, edinilen bilgiyi disiplinler arası yaklaşımla işleme firsatı sağlamayı amaçlamaktadır. Ön test ve son test kontrol gruplu ampirik desen kullanılan bu çalışmada özel yetenekli öğrencilerin, durumlarına ilişkin akademik gelişimlerinin desteklenmesinin yanı sıra, söz konusu bireylerin eğitiminde doğru performans ölçme değerlendirme yöntem ve araçları kullanıldığında yetenekli oldukları alanda daha hızlı ilerleyebilecekleri gerçeği de tespit edilmiştir.

\subsection{Problem Cümlesi}

Türk mûsıkîsi usûl eğitiminde Dalcroze öğretim yöntemi teknikleri ile hazırlanan öğretim yaklaşımlarının zencîr usûlü üzerinde kullanılabilirlik düzeyi?

\subsection{Alt Problemler}

1. Öğrencilerin, zencîr usûlünde kullanılan nota değer işaretlerini tanıyabilme becerileri ne düzeyde gelişmiştir?

2. Öğrencilerin, nota değer işaretlerinin konumlandırıldığ1 usûl çizgilerinin özelliklerini tanıyabilme becerileri ne düzeyde gelişmiştir?

3. Öğrencilerin, zencîr usûlünde sağ ve sol el tekniklerinde kullanılan ikâları (düzüm) yapabilme becerileri ne düzeyde gelişmiştir?

4. Öğrencilerin, zencîr usûlündeki ikâları doğru tempo ile icrâ becerileri ne düzeyde gelişmiştir? 
Tamay, S., \& Dönmez Devecioğlu, N. (2021). Türk mûsıkîsi usûl eğitiminde Dalcroze öğretim yöntemi ile zencîr usûlünün ögrenilebilirlik düzeyi. Journal of Human Sciences, 18 (2), 215-232. doi: 10.14687/jhs.v18i2.6101

5. Öğrencilerin, zencîr usûlünde bestelenmiş bir esere eşlik etme becerileri ne düzeyde gelişmiştir?

6. Öğrencilerin, zencîr usûlünü bedensel hareketle icrâ etme becerileri ne düzeyde gelişmiştir?

\section{ARAŞTIRMA MODELI}

Araştırmanın modelini ön test - son test kontrol gruplu model oluşturmuştur. Tecrübi çalışmalarda görülen temel sorunlardan birisi katılımcıların seçimidir ve bu durum test bazlı kontrol gruplu desenlerde büyük önem arz eder. Söz konusu önem, bağımlı değişkene ait tecrübe ve kontrol gruplarının puanlarının yapılan uygulama sonrasındaki farklılıklarının uygulama öncesi farklılıklardan kaynaklanabilir olabileceği sebep - sonuç ilişkisi nedeniyledir. "Bununla birlikte ön test - son test kontrol gruplu desenin, deneysel işlemin bağımlı değişken üzerindeki etkisinin test edilmesiyle ilgili olarak araştırmaciya yüksek bir istatistiksel güç sağlayan, elde edilen bulguların neden - sonuç bağlamında yorumlanmasına olanak veren ve davranış bilimlerinde sıklıkla kullanılan güçlü bir desen olduğu söylenebilir” (Büyüköztürk, 2014, s. 24).

\section{1 Çalışma Grubu}

Çalışma grubu, 2020 - 2021 Eğitim - Öğretim yılında Akhisar Bilim ve Sanat Merkezi özel yetenekli müzik öğrencilerinden $(\mathrm{n}=8)$ oluşmaktadır.

Öğrenciler gönüllülük ilkesine uygun olarak seçilmiş olup, velilerin yazılı müsaadeleriyle katılmıslardır.

\subsection{Veri Toplama Araçları}

Veri toplama aracında test bazlı kontrol gruplu deneysel desen kullanılmıştır. Akhisar Bilim ve Sanat özel yetenekli müzik öğrencilerin seviyeleri, denklik testi sonuçları ile belirlenmiştir. Ön test son test aşamalarında Performans Değerlendirme Ölçeği kullanılmıştır. Kullanılmış ölçeklerin korelasyon katsayı değerleri 0 , 92 olarak hesaplanmıştır. Bu veri, çalışmanın güvenilirliği, doğrultusunda olumlu sonuç göstergesidir.

2020 - 2021 Eğitim - Öğretim y1l güz döneminde Akhisar Bilim ve Sanat Merkezinde uzaktan eğitim öğretim sistemi müzik dersi "120 Zamanlı Zencîr Usûlü” başılklı ders konusu kapsamında yapılmıştır.

\subsubsection{Denklik Testi}

Grupların dengeli bir biçimde dağıtılması amacıyla katılımcılara onar soruluk denklik testi uygulanmıştır.

Katılımcıların başlangıçtaki farklılıklarının en aza indirgemesinin yolunun onların uygun yöntemlerle gruplara atanmasından geçtiğini belirten Büyüköztürk'e göre, “deneklerin iki gruba ayrılmasında izlenen iki temel yöntemden biri eşleştirme, diğeri yansız atamadır” (Büyüköztürk, 2014, s. 22).

Bu çalışmada da, sorunsal, iki grup üzerinden incelenmiştir. Çalışmanın sağlıklı bir biçimde yürütülmesi için öncelikle, denklik testi uygulanması ön görülmüştür. Grupların oluşturulması için 2019 - 2020 Eğitim - Öğretim yllı Akhisar Bilim ve Sanat Merkezinde uygulanan müfredat kazanımlarına uygun olarak temel müzik yazı ve ögeleri konularından 10 adet çoktan seçmeli bir test uygulanmıştır.

Testin cevaplandırılabilmesi için öğrencilerin adlarına düzenlenen soru kâğıtları hazırlanmıștır. Araştırmanın uygulama zamanında Millî Eğitim Bakanlığına bağlı eğitim kurumlarında uzaktan eğitim uygulandığından soruların sorulması ve cevaplanması dijital ortamda Zoom uygulaması üzerinden online olarak soru-cevap biçiminde gerçekleştirilmiştir.

Denklik testi uygulama zamanı, katılımcı öğrencilerle bireysel olarak önceden görüşülerek belirlenmiştir. Denklik testinde her öğrenci için 20 dakika süre verilmiş ve aynı sorular sorulmuştur. Denklik testi 100 tam puan üzerinden puanlandırılmış ve sonuçlandırlmıştır. 
Tamay, S., \& Dönmez Devecioğlu, N. (2021). Türk mûsıkîsi usûl eğitiminde Dalcroze öğretim yöntemi ile zencîr usûlünün ögrenilebilirlik düzeyi. Journal of Human Sciences, 18 (2), 215-232. doi: 10.14687/ihs.v18i2.6101

Bu sonuçlar doğrultusunda grupların atamaları yapılmıştır. Grup atamaları, (kontrol ve deney) puan eşitlikleri sağlanarak yansız atama yoluyla gerçekleştirilmiştir.

\subsection{2 Ön Test ve Son Test}

$\mathrm{Bu}$ süreçte ilk olarak çalışma grubu öğrencilerine ön test aşaması uygulanmıştır. 8 haftalık deneysel işlem sürecinden sonra ön test aşamasında kullanılan sorulara hiçbir müdahale edilemeden son test aşaması uygulanmıştır.

Testlerdeki dereceli puanlama anahtarının geçerliliğinin onayı için 10 maddeli ve her bir madde için 5 seçenekli uzman görüşü alma formu düzenlenmiştir. Bu düzenlemede öğretim sistemi ve test aşamalarında (ön test - son test) katılımcıların çalışmalara uyumluğunun, davranışlarını ölçecek olan dereceli puanlama anahtar içeriğinin (sorular, cevap seçenekleri, uygulama süreleri ve puanlama anahtarının tekniği) sorgulanması ve denetlenmesi gözetilmiştir.

Bu doğrultuda, üniversitelerin müzik bölümlerinden iki eğitimci uzmanın görüşleri alınmış ve karşılaştırılmıştır. Puanlayıcılar arasındaki çalışma güvenirlik katsayısı 0, 86 olarak bulunmuştur. Bu sonuç, araştırmanın güvenilirliğinin yüksek olduğunu ortaya koymaktadır.

Öğrencilerin tüm aşamalara ait performans içerikli video kayıtları gerçekleştirilerek alanında uzman müzik eğitimcilerine sunulmuş ve değerlendirmeleri yapılmıştır. Edinilen bulgular "Statistical Package for the Social Sciences 20" (SPSS 20) programına aktarılmıştır.

\subsection{Verilerin Analizi}

"Mann - Whitney U Testi iki ilişkisiz örneklemden elde edilen puanların birbirlerinden anlamlı bir şekilde farklılık gösterip göstermediğini test etmek için kullanılmaktadır" (Büyüköztürk, 2010, s. 155). Burada, veri analizleri yapılırken önem düzeyi eşiği olarak farklı rakamlar kabul edilebilir.

\subsection{Usûl}

"Ritim, belirli bir zamanın kendi içinde bölünmesidir. Bu bölünmeler rastgele değil, belirlenen zaman bölmelerinin uzunluklarına göre düzenlenmektedir. Zaman bölmeleri ya da bölünmüş zamanlar bir araya (yan yana) getirildiğinde, ritim kalıpları oluşmaktadır"(Çelak, 2010, s. 10). Türk müziğinin kendine özgü ritmik oluşumuna usûl terimi kullanılmaktadır. Türk müziği makamsal ezgilerinin yanısıra usûl çeşitliliği bakımından da oldukça zengin bir yapıdadır.

Bilindiği üzere, notaların (ses ve susku) sürelerini belirlemek için yapılan sayma hareketlerine 'vuruş' denir. "Vuruşların kıymetleri birbirine eşit veya eşit olmayan, fakat mutlaka, muhtelif kuvvetli, yarı kuvvetli ve zayıf zamanların belli bir şekilde sıralanmasıyla meydana gelen belli kalıplar halindeki say1 veya vuruş gruplarına usûl denir" (Özkan, 1998, s. 561).

“Türk Mûsıkîsinde usûller zamanlarının büyüklük ve küçüklüklerine göre iki kümeye ayrılmıştır. On beş zamana kadar olan usûllere küçük usûller, diğerlerine büyük usûller denilmiştir (Yay, 2010, s. 9). "Kendinden daha küçük usûllere ayrilmayan usûllere basit usûl denir" (Çakar, 1996, s. 27).

Usûllerin vuruluşunda ve tarifinde özel bir şekle ihtiyaç bulunmaktadır. Bu şekil dikdörtgen biçiminde bulunan çizgilere notalar aracillğıyla belirtilir. "Bu paralel ve yatay çizgilerin baş tarafina usûl rakamları, üst çizgiye sağ el ile vurulan vuruşlar, alt çizgiye sol el ile vurulan vuruşlar, usûlün zaman birimine ve vuruşlardaki zaman birimi adedine göre nota değeri ile yazılır (Çakar, 1996, s. 24).

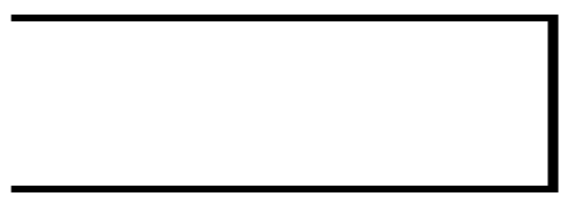

Şekil 2.1. Usûl Çi̊ggisi 
Tamay, S., \& Dönmez Devecioğlu, N. (2021). Türk mûsıkîsi usûl eğitiminde Dalcroze öğretim yöntemi ile zencîr usûlünün ögrenilebilirlik düzeyi. Journal of Human Sciences, 18 (2), 215-232. doi: 10.14687/ihs.v18i2.6101

\subsection{Dalcroze Öğretim Yöntemleri}

"Dalcroze yaklaşımı, Emile Jaques-Dalcroze tarafından, Kodaly, Orff gibi müzik öğretim yaklaşımlarından önce oluşturulmuş bir müzik öğretim yaklaşımı olarak 20. yüzyılda geliştirilmiş ilk müzik eğitimi felsefelerindendir" (Tufan, 2011, s. 22). "Dalcroze öğrenme yöntemini geliştiren İsviçreli besteci Emile - Jacques Dalcroze (1865-1950)'dir. Zihin ve beden arasındaki uyum doğaçlama ve beden hareketleri ile gösterilir. Bu yöntemde hareket esastır. Çocuklar duydukları müziği kendilerine göre ifade etme firsatı elde etmiş olurlar" (Çevik, 2007, s. 96). "İlk deneyimlerini 1903 yılında, Cenevre de gerçekleştiren Dalcroze, insanın sahip olduğu yeteneklerin tümünü ya da mümkün olduğu kadar çoğunu aynı anda ortaya çıkaracak etkilerin gerekliliğine inanmaktadır" (Yıldırım, 1995, s. 2). "Dalcroze yaklaşımının amaçları arasında; Dikkat, mükemmel duyuş, müziksel okuma ve yazma, tonalite, dizi ve kadansları anlama, müziksel hafıza geliştirme gibi yeteneklerin kazandirılması da vardır" (Tufan, 2011, s. 31).

"Bedenin, sesleri çalg1 gibi yorumlama yöntemini içerir. Birey müziğin ritmini, ezgisel dolanımını, müziğin anlatımını (hız, gürlük, ayırtı) ses ve bedeniyle eyleme dönüştürür. Başka bir deyişle birey ezgi bütünselliğe yoğunlaşarak (konsantrasyon) beyni ve bedeniyle müziği yorumlar" (Gedikli, 2007, s. 45). "Çocuklar müziğe uyarak serbest ritmik hareketler yapar, müziğe göre yürür, oynar, atlar, zıplar, el çırparlar. Böylece bedensel hareketlerle kendilerine ifade etme firsatını bulurlar ve bundan son derece zevk duyarlar" (Yıldız, 2002, s. 64). "Müzikal anlamda kendini ifade edebilmek için, müzikal kavramların yerine konulan bir dizi hareket benzeşimleri kullanılır. Dalcroze`a göre sağlam ve canlı bir müzikal temel oluşturmanın en iyi yolu, insan bedenini çok iyi akortlanmış bir müzik aletine dönüştürmektir” (Karaarslan, 2015, s. 12).

"Dalcroze; ritmik hareketlerin ve müzikle uyumun geliştirilmesi için yapılacak çalışmaları üç bölümde değerlendirmiştir:

1. Ritmik hareketler

2. İşitme çalışmaları

3. Doğaçlamalar" (Peşinci, 2014, s. 10).

\subsubsection{Ritmik Hareketler}

"Eurhythmics, kısaca İsviçreli eğitmen Dalcroze un geliştirdiği, doğuştan sahip olduğumuz müzikselliği bilinçli bir yaklaşımla ritmik hareket, kulak eğitimi ve doğaçlama yoluyla sistemleştirdiği bir müzik eğitimi yaklaşımıdır" (Özdemir Tuncer, 2012, s. 21).

"Eurhythmics'te kullanılan anlamıyla "dinamik", vücuttaki kas enerjisinin değişik aşamalarını ifade eder. Yaşamda bu aşamalar veya enerji farklılıkları, ifadeleri ve ruh hallerini yansıtır. Örneğin öfke durumunda kaslar kuvvetlice kasılır, üzüntü durumunda gevşer. Ruh halinin fiziksel dışavurumu olan bu durum müziğe de yansımıştır” (Tufan, 2011, s. 31).

\subsection{2 İşitme Çalışmaları}

\subsubsection{Solfej Eğitimi}

"Dalcroze'un müzikal olarak okuma ve yazma çalışmaları, yani bir anlamda solfej eğitimi, eğitim yaklaşımının diğer aşamalarındaki prensipleri içerir. Öğretim şekli, eurhythmics ve doğaçlama aşamalarındaki süreçlerle iç içe geçmiş, benzer yapıdadır” (Tufan, 2011, s. 32).

\subsubsection{Kulak Eğitimi}

Kulak eğitiminde, öğrencilerin yüksek seviyede dinleme/duyma yeteneğine sahip olmaları beklenir ve içsel duyumlarının gelişimi esas kabul edilir. 
Tamay, S., \& Dönmez Devecioğlu, N. (2021). Türk mûsıkîsi usûl eğitiminde Dalcroze öğretim yöntemi ile zencîr usûlünün ögrenilebilirlik düzeyi. Journal of Human Sciences, 18 (2), 215-232. doi: 10.14687/ihs.v18i2.6101

\subsubsection{Doğaçlamalar}

"Dalcroze derslere müziğin ritmine uygun yürüme hareketi ile baslar ve öğrencilerden ne duyuyorlarsa ona göre hareket etmelerini ister. Böylece yaratıcilığın temelleri doğaçlama ile atılmış olur. Doğaçlama Dalcroze’un en önemli öğesidir" (Özcan, 2007, s.44). "Dalcroze yönteminin bütününü oluşturan bu temel aşamalar birbirinden bağımsız değildir; aksine birbirleriyle iç içe geçmişlerdir ve kesiştikleri noktalar anlamında birbirlerini kapsarlar” (Tufan, 2011, s. 34).

"Ülkemizde Eurhythmics eğitimi özengen eğitim veren MEB'e bağlı sanat merkezleri ve kurslarda özellikle erken müzik eğitimi adı altında henüz yaşı enstrüman çalmaya müsait olmayan öğrencilere küçük gruplar halinde verilmektedir" (Peşinci, 2014, s. 10).

Psiko - motor becerileri gelişmeyen öğrencilere verilen ritim eğitimleri müzik eğitiminin ilk aşamaları olarak görülebilir. Bu eğitimler öğrencilerin müzik sevgisini de geliştirebilir.

\subsection{Deneysel İşlem}

Öğretim sistemi, eğitim - öğretim programlarının hedefleri yönünde öğrencilere kazandırılması hedeflenen bilgi, beceri ve davranışların planlı şekilde düzenlenmesiyle oluşturulan uygulamaya yönelik sistematik bir yapıdır. Bu çalışmada, söz konusu etkinlikler 8 haftalık uzaktan eğitim ders planlaması ve çalışma grupları ile haftada 2 ders saati (30 dakika) şeklinde uygulanmıştır.

Öğretim sistemi içerisinde nota değer işaretleri, usûl, küçük ve büyük usûller, zencîr usûlü ve bu usûlü oluşturan usûller, zencîr usûlü ile ilgili eser örnekleri bulunmaktadır.

Ünite içeriklerinde kazanılması gereken kazanımlar önceden düzenlenmiş ve derslere eşit biçimde dağıtılarak uygulanmışır.

\subsubsection{Deneysel İşlem Kazanımları ve Uygulama Biçimi}

Öğretim sisteminde kazanımların sağlanması açısından bu çalışmada kazanımlara rumuz sistemi uygulanmıştır. Kullanılan bu rumuzların amacı deneysel işlem uygulamalarında kolaylık sağlaması açısından düzenlenmiştir. Deneysel kazanım rumuz sistemine ait uygulamanın zaman çizelgesi Tablo 2. 2. `de sunulmuştur.

Tablo 2.1. Deneysel İslem Zaman Çizelgesi

\begin{tabular}{|c|c|c|}
\hline $\begin{array}{c}\text { İşlenecek Ders } \\
\text { Haftaları }\end{array}$ & $\begin{array}{c}\text { Deneysel } \\
\text { İşlem } \\
\text { Kazanım } \\
\text { Rumuzları }\end{array}$ & Deneysel İşlem Kazanımı Başlıkları \\
\hline 1. 2 . & $\mathrm{A}$ & Nota değer işaretleri \\
\hline 1. 2 . & B & Usûl nazariyat1 \\
\hline 1. 2 . & $\mathrm{C}$ & Küçük usûller \\
\hline 1.2.3.4. 5.6.7.8. & $\mathrm{D}$ & Büyük usûller \\
\hline 3. 4. 5.6.7.8. & $\mathrm{E}$ & Çifte düyek usûlü \\
\hline 3. 4. 5.6.7.8. & $\mathrm{F}$ & Fahte usûlü \\
\hline 4. 5. 6. 7.8. & G & Çember usûlü \\
\hline 4. 5. 6. 7.8. & $\mathrm{H}$ & Devr - i kebîr usûlü \\
\hline 5. 6. 7.8 . & I & Berefşân usûlü \\
\hline 5. 6. 7.8 . & $\mathrm{J}$ & Zencîr usûlü \\
\hline 5. 6. 7.8 & $\mathrm{~K}$ & Zencîr usûlü besteleri \\
\hline 2. 3. 4. 5.6.7.8. & $\mathrm{L}$ & Dalcroze öğretim yöntemi ile usûl çalışmaları \\
\hline
\end{tabular}


Tablo 1'de sunulan deneysel işlem kazanım rumuzları (A - B - C - D - E - F - G - H - I $\mathrm{J}$ - K - L) biçiminde düzenlenmiştir. Düzenlenen deneysel işlem kazanımlarında bilinenden bilinmeyene, somuttan soyuta ilkesi doğrultusunda ve sistematik bir biçimde hazırlanmıştır.

Rumuzlarla ilişkilendirilen deneysel işlem kazanım açıklamaları başlık ve alt başlıklar biçiminde sunulmuştur.

\subsubsection{Nota Değer İşaretleri (A Kazanımı)}

A rumuzlu deneysel işlem kazanımında, nota değer işaretleri çalışmaları yer almaktadır.

Bu çalışmada öğrencilerin nota işaretlerinin farklılıklarını ayırt etme becerisi ve her işaretin temsil ettiği değerlerinin kazanımı sağlanmaktadır. Bu konu başlı̆̆ında öğrencilere nota işaretleri gösterilerek değerlerinin söylenmesi istenmiştir.

$\mathrm{Bu}$ konu başlı̆̆nda Şekil 2. 1.'de sunulan yani ana kazanımımız olan zencîr usûlünde kullanılan nota değer işaretleri ile sınırlıdır.

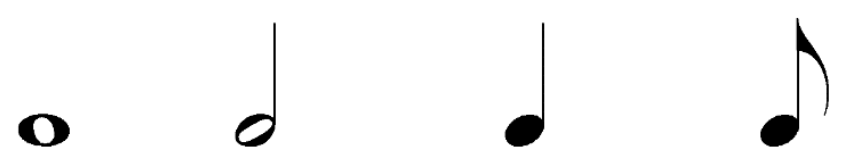

Şekil 2.2. Nota Değer İsaretleri

\subsubsection{Usûl Nazariyatı (B Kazanımı)}

Bu kazanımda Türk mûsıkîsinde kullanılan usûl sisteminin genel tanıtımı yapılmaktadır.

Usûl nazariyatında kullanılan usûl şekil tablosunun ifade biçimi, usûllerde kullanılan ikâ, darp ve darp esnasında telaffuz edilen özel kelime ve sözcükler, küçük ve büyük usûllerin kazanımlarının genel hatlarıyla sinirlidır.

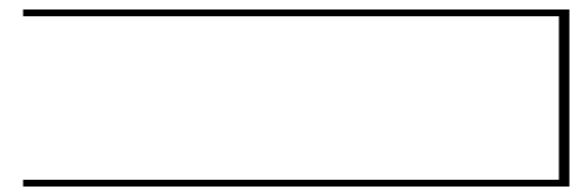

Şekil 2.3. Usûl Çizgileri

\subsubsection{Küçük Usûller (C Kazanımı)}

Küçük Usûller; 2 zamanlıdan 15 zamanlıya kadar oluşan usûlleri kapsamaktadır.

$\mathrm{Bu}$ usûller birebir zencîr usûlü içinde mevcut durumunda değildir. Ancak çalışmamızın genel sisteminde bilinenden bilinmeyene ilkesi ve doğrusal sistem bünyesinde olduğundan bu usûllerin de kazanımlar içerisinde olması kararlaşııılmıştır.

\subsubsection{Büyük Usûller (D Kazanımı)}

Büyük Usûller; 16 zamanlıdan 120 zamanlıya kadar oluşan usûlleri kapsamaktadır.

Zencîr usûlü 120 zamanlı usûldür ve büyük usûller grubu içerisinde yer almaktadır.

Zencîr usûlü bünyesinde 5 adet büyük usûl vardır. Bu usûller, çifte düyek, fahte, çember, devr - i kebîr ve berefşan usûlleridir. 


\subsubsection{5 Çifte Düyek Usûlü (E Kazanımı)}

E kazanımında öğrencilere çifte düyek usûlünün sağ ve sol el icrâ gösterimi, ifadesi, tasnifi bu usûlle bestelenmiş örnek ezgi ve eserlerle usûl icralarının uygulanması istenmiştir.

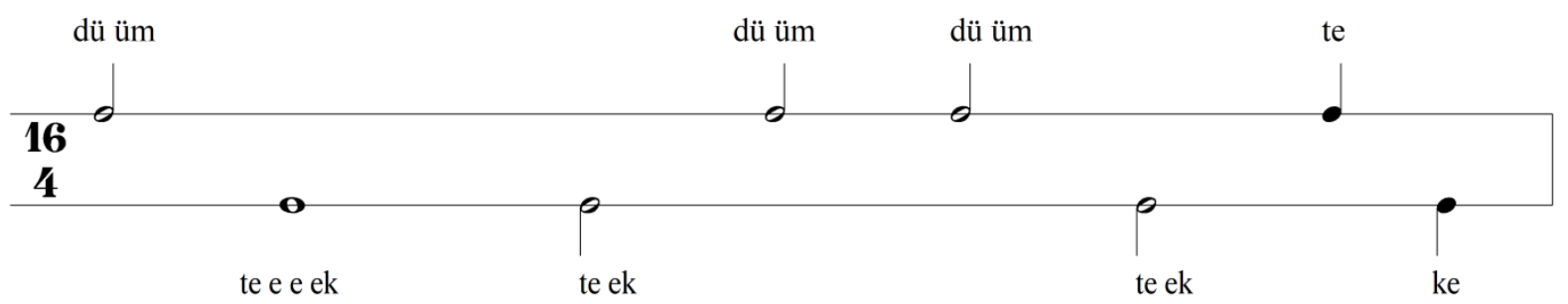

\subsubsection{Fahte Usûlü (F Kazanımı)}

Şekil 2.4. Çifte Düyek Usûlü

F kazanımında öğrencilere fahte usûlünün sağ ve sol el gösterimi, ifadesi, tasnifi bu usûlle bestelenmiş örnek ezgi ve eserlerle usûl icralarının uygulanması istenmiştir.

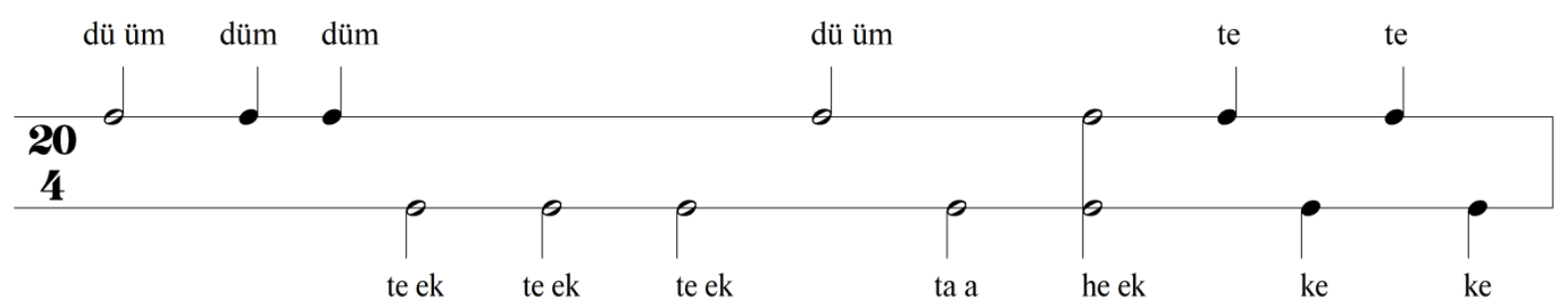

\subsubsection{7 Çember Usûlü (G Kazanımı)}

Şekil 2.5. Fabte Usûlü

G kazanımında öğrencilere çember usûlünün sağ ve sol el icrâ gösterimi, ifadesi, tasnifi bu usûlle bestelenmiş örnek ezgi ve eserlerle usûl icralarının uygulanması istenmiştir.

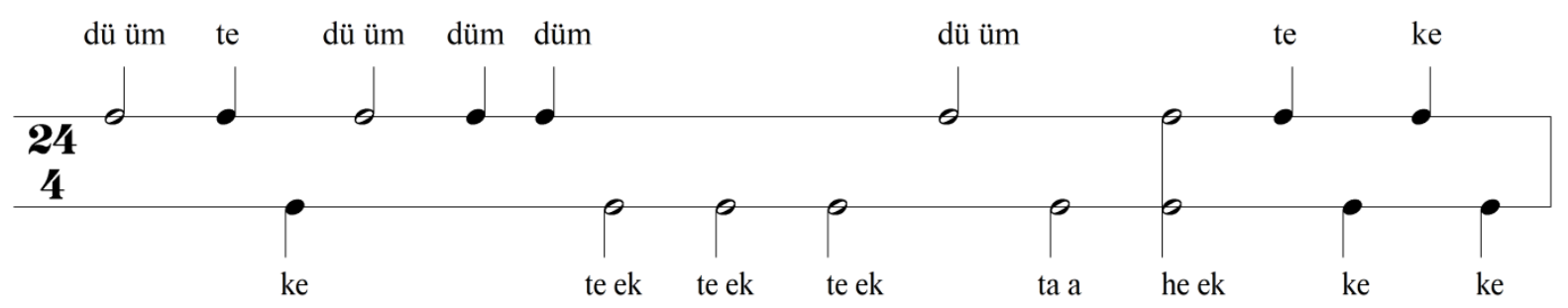

Şekil 2.6. Cember Usûlü

\subsubsection{Devr - i Kebîr Usûlü (H Kazanımı)}

H kazanımında öğrencilere devr - i kebîr usûlünün sağ ve sol el icrâ gösterimi, ifadesi, tasnifi bu usûlle bestelenmiş örnek ezgi ve eserlerle usûl icralarının uygulanması istenmiştir.

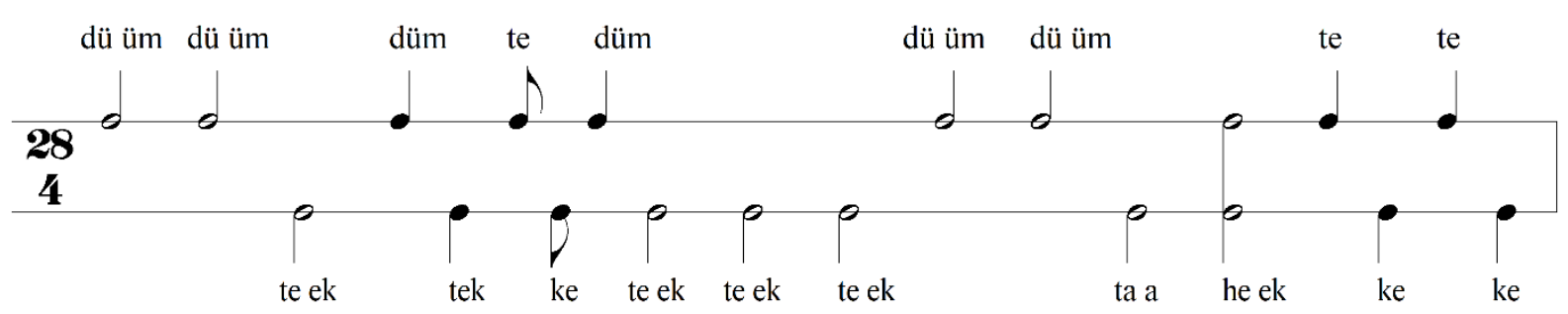

Şekil 2.7. Devr - i Kebîr Usûlü 


\subsubsection{Berefşân Usûlü (I Kazanımı)}

H kazanımında öğrencilere berefşân usûlünün sağ ve sol el icrâ gösterimi, ifadesi, tasnifi bu usûlle bestelenmiş örnek ezgi ve eserlerle usûl icralarının uygulanması istenmiştir.

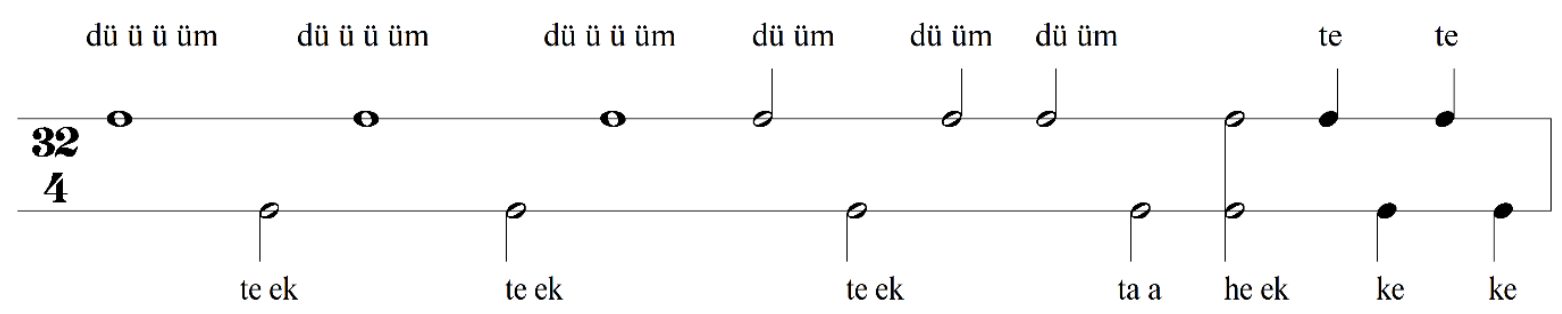

\subsubsection{Zencîr Usûlü (J Kazanımı)}

Şekil 2.8. Beref̧̧ân Usûlü

J kazanımında öğrencilere zencîr usûlünün sağ ve sol el icrâ gösterimi, ifadesi, tasnifi bu usûlle bestelenmiş örnek ezgi ve eserlerle usûl icralarının uygulanması istenmiştir.
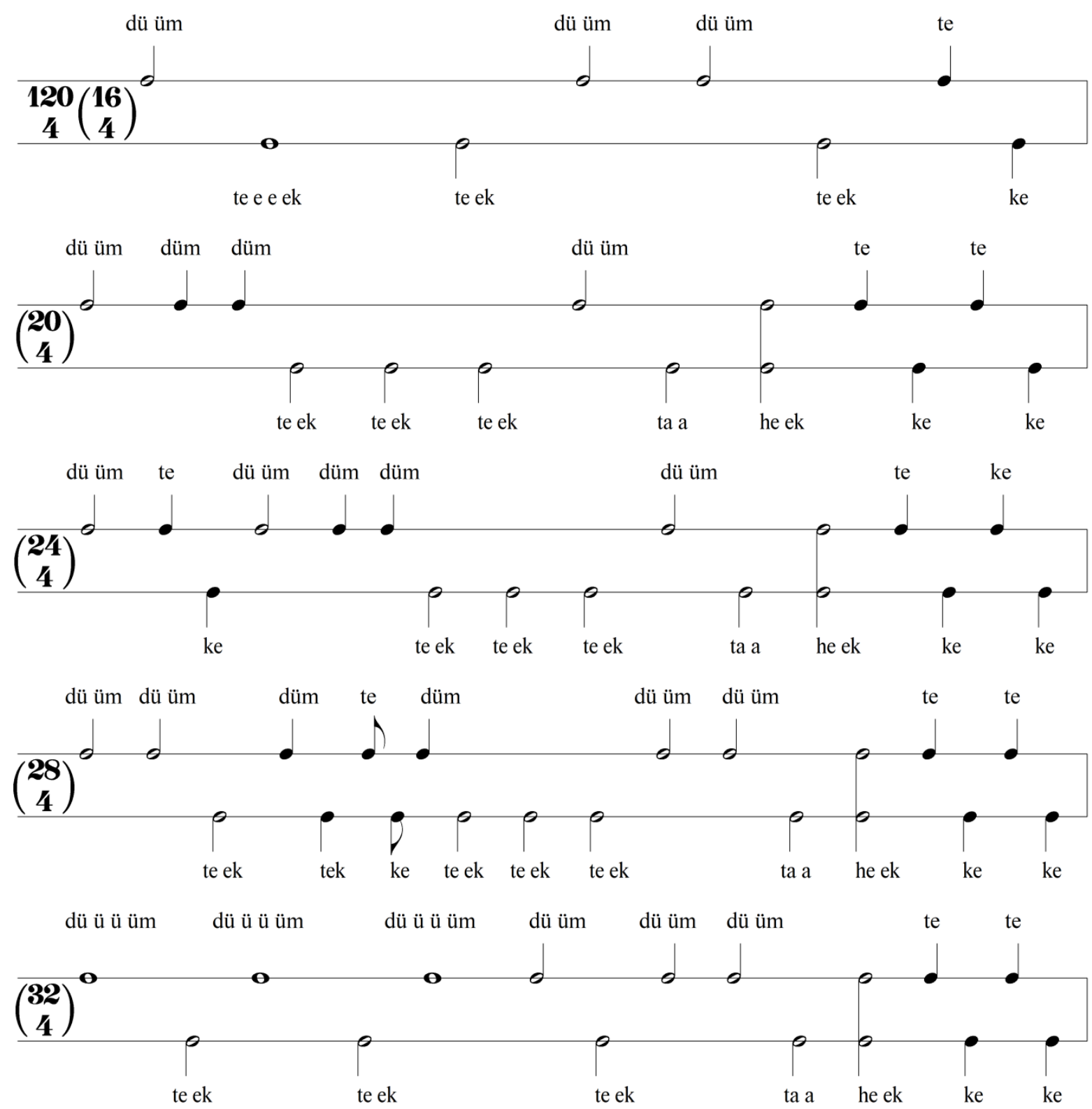

Şekil 2.9.Zencîr Usûlï 
Tamay, S., \& Dönmez Devecioğlu, N. (2021). Türk mûsıkîsi usûl eğitiminde Dalcroze öğretim yöntemi ile zencîr usûlünün ögrenilebilirlik düzeyi. Journal of Human Sciences, 18 (2), 215-232. doi: 10.14687/ihs.v18i2.6101

\subsubsection{Zencîr Usûlüne Örnek Eserler (K Kazanımı)}

K kazanımında zencîr usûlünde bestelenmiş eserler dinletilir. Bu eserler hakkında bilgilendirmeler yapılır. Bestenin güfte ve beste yazarları, güftelerde Türkçe olmayan kelimelerin anlamları ve güfte bütünlügünde anlatılmak istenen kompozisyonu, eserin makamı ve eserin metronom hızları hakkında açıklamalar yapılır.

Zencîr usûlünde bestelenmiş eserlerin usûl icralarında öncelikli olarak 5 bölüme ayrilarak (usûl içinde bulunan usûller doğrultusunda) usûl icrası yapıllır. Sonra bölümler sırasıyla birleştirilerek usûlün tüm biçimde vurulmast istenir.

\subsubsection{Dalcroze Öğretim Yöntemi ile İlişkilendirilmiş Usûl Çalışmaları (L Kazanımı)}

Bu kazanım, ritmik yönetim, müzikal duyarlllı̆̆ı geliştirmeyi amaçlayan bir disiplindir. Antik Yunan'da "müzikle beden hareketi birdir, ayrılamaz düşüncesiyle Dalcroze öğretim yöntemini solfej - kulak eğitimi, hareket ve doğaçlama başlıkları altında almıştır. Bu doğrultuda zencîr usûlünü müzikal anlamda Dalcroze öğretim yöntemi bünyesinde uygulanması istenmiştir.

Bu yöntem doğrultusunda usûl icrâlarının geleneksel yöntem olarak sağ ve sol el ile sağ ve sol dizlere darbıyla gerçekleşmektedir. Ancak bu çalışmada usûllerin bu icrâ biçiminin kazanımına değişik yöntem ile daha kalıcı, kolay ve eğlenceli biçimde sağlanmaktadır.

Bu kazanım, bu çalışmamızın ana kazanımları ve hedef kazanımlarımızda yer almaktadır.

\section{BULGULAR}

Bu bölümde, çalısmada uygulanan ön test ve son test puanlarının Mann - Whitney U Testi verileri sunulmuştur.

\subsection{Alt Problem Doğrultusunda Bulgu Sonuçları}

Öğrencilerin zencîr usûlünde kullanılan nota değer işaretlerini tanıyabilme becerileri ölçülmüş ve sonuç verileri Tablo 3. 1.`de sunulmuştur.

Tablo 3.1. Zencîr usûlünde kullamlan nota değer işaretlerini tanuyabilme becerilerine yönelik ön test verileri

\begin{tabular}{lcccccc}
\hline Grup & n & Sira Ortalaması & Sira Toplamı & U & Z & p \\
\hline Deney & 4 & 5.25 & 21 & 5.000 & -.949 & .343 \\
Kontrol & 4 & 3.75 & 15 & & & \\
\hline Toplam & 8 & & & & & \\
\hline
\end{tabular}

Tablo 3. 1. İncelendiğinde kontrol ve deney grubu öğrencilerinin zencîr usûlünde kullanılan nota değer işaretlerini tanıyabilme becerilerine ilişkin puanlarında istatistiksel açıdan belirgin fark yoktur. (U=5,000; $\mathrm{p}>0.05)$. Sira ortalamaları incelendiği zaman deney grubu öğrencileri lehine yüksek bir ortalamaya ulaşılmıştır. Bu ortalamanın istatistiksel açıdan önemli bir farka yol açmadığ söylenebilir.

$\mathrm{Bu}$ sonuçlarla birlikte öğrencilerin zencîr usûlünde kullanılan nota değer işaretlerini tanıyabilme becerilerinin son test sonuçları belirlenmiştir.

Tablo 3.2. Zencîr usûlünde kullanulan nota değer işaretlerini tanyabilme becerilerine yönelik son test verileri

\begin{tabular}{lcccccc}
\hline Grup & n & Sira Ortalamas1 & S1ra Toplami & U & Z & p \\
\hline Deney & 4 & 6.5 & 26 & \multirow{2}{*}{.000} & -2.530 & .011 \\
Kontrol & 4 & 2.5 & 10 & & & \\
\hline Toplam & 8 & & & & & \\
\hline
\end{tabular}


Tamay, S., \& Dönmez Devecioğlu, N. (2021). Türk mûsıkîsi usûl eğitiminde Dalcroze öğretim yöntemi ile zencîr usûlünün ögrenilebilirlik düzeyi. Journal of Human Sciences, 18 (2), 215-232. doi: 10.14687/ihs.v18i2.6101

Tablo 3. 2. incelendiğinde kontrol ve deney grubu öğrencilerinin zencîr usûlünde kullanılan nota değer işaretlerini tanıyabilme becerileri ortaya konmuştur. Bu noktada önemli bir sonuç göze çarpmakta ve öğrencilerin son test puanlarında istatistiksel açıdan belirgin fark vardır. (U=,000; $\mathrm{p}<0.05)$. Test sonuç verileri göstermektedir ki, deney grubunda verilen eğitimin öğrencilerin zencîr usûlünde kullanılan nota değer işaretlerini tanıyabilme becerilerini önemli ölçüde artırmıştır.

\subsection{Alt Problem Doğrultusunda Bulgu Sonuçları}

Öğrencilerin nota değer işaretlerinin konumlandırıldığı usûl çizgilerinin özelliklerini tanıyabilme becerileri ölçülmüş ve sonuç verileri Tablo 3. 3. `te sunulmuştur.

Tablo 3.3. Nota değer işaretlerinin konumlandirldiğ usûl çizgilerinin özelliklerini tanyabilme becerilerine yönelik ön test verileri

\begin{tabular}{llccccc}
\hline Grup & n & Sira Ortalamas1 & Sira Toplami & U & Z & p \\
\hline Deney & 4 & 3.5 & 14 & 4.000 & -1.528 & .127 \\
Kontrol & 4 & 5.5 & 22 & & & \\
\hline Toplam & 8 & & & & & \\
\hline
\end{tabular}

Tablo 3. 3. incelendiğinde nota değer işaretlerinin konumlandırıldığı usûl çizgilerinin özelliklerini tanıyabilme becerilerine ilişkin puanlarında istatistiksel açıdan belirgin fark yoktur. $(\mathrm{U}=4,000 ; \mathrm{p}>0.05)$. Sira ortalamaları incelendiğinde kontrol grubu deney grubuna nazaran nota değer işaretlerinin konumlandırıldığı usûl çizgilerinin özelliklerini tanıyabilme becerilerinden yüksek ortalamaya sahip oldukları anlaşılmaktadır. Bu sonucun istatistiksel açıdan önemli fark yoktur denilebilir.

Öğrencilerin nota değer işaretlerinin konumlandırıldığ1 usûl çizgilerinin özelliklerini tanıyabilme becerileri tespit edilmiştir. Bu süreçte, Mann - Whitney U Testi uygulanmış ve istatistiksel açıdan belirgin bir farkın olup olmadığını gösteren sonuçlar Tablo 3. 4. 'te sunulmuştur.

Tablo 3.4. Nota değer işaretlerinin konumlandirnldı̆̆ usûl çizgilerinin özelliklerini tanyabilme becerilerine yönelike son test verileri

\begin{tabular}{lcccccc}
\hline Grup & $\mathbf{n}$ & Sira Ortalamas1 & Sira Toplami & U & Z & p \\
\hline Deney & 4 & 5 & 20 & \multirow{2}{*}{6.000} & -.667 & \multirow{2}{*}{.505} \\
Kontrol & 4 & 4 & 16 & & & \\
\hline Toplam & 8 & & & & & \\
\hline
\end{tabular}

Tablo 3. 4. 'te sunulan veriler doğrultusunda kontrol ve deney grubu öğrencilerinin nota değer işaretlerinin konumlandırıldığı usûl çizgilerinin özelliklerini tanıyabilme becerilerine yönelik son test puanlarında istatistiksel olarak belirgin bir farka ulaşılmamıştır $(\mathrm{U}=6,000 ; \mathrm{p}>0.05)$. Sıra ortalamaları ise deney grubunun nota değer işaretlerinin konumlandırıldığ1 usûl çizgilerinin özelliklerini tanıyabilme becerileri doğrultusunda yüksek ortalamaya sahip olduklarını işaret etmektedir. Anlaşılmaktadır ki bu ortalama, istatistiksel yönden belirgin bir fark olarak açıklanmamaktadır. $\mathrm{Bu}$ noktada, deney grubunda verilen eğitimin nota değer işaretlerinin konumlandırıldığ1 usûl çizgilerinin özelliklerini tanıyabilme becerilerini önemli ölçüde artırmadığı görülmektedir.

\subsection{Alt Problem Doğrultusunda Bulgu Sonuçları}

Çalışma grubu öğrencilerinin zencîr usûlünde sağ ve sol el tekniklerinde kullanılan ikâları (düzüm) yapabilme becerileri sınanmıştır. Bu aşamada ki ön test sonuçlarında istatistiksel yönden belirgin bir farka ulaşılıp ulaşılmadığı belirlenmiş ve sonuç verileri Tablo 3. 5. ‘te sunulmuştur. 
Tamay, S., \& Dönmez Devecioğlu, N. (2021). Türk mûsıkîsi usûl eğitiminde Dalcroze öğretim yöntemi ile zencîr usûlünün öğrenilebilirlik düzeyi. Journal of Human Sciences, 18 (2), 215-232. doi: 10.14687/jhs.v18i2.6101

Tablo 3.5. Zencîr usûlünde săg ve sol el tekniklerinde kullanulan ikâlar (dü̃üm) yapabilme becerilerine yönelik. ön test verileri

\begin{tabular}{lcccccc}
\hline Grup & $\mathbf{n}$ & Sira Ortalaması & Sira Toplamı & U & Z & p \\
\hline Deney & 4 & 4.5 & 18 & \multirow{2}{*}{8.000} & .000 & 1.000 \\
Kontrol & 4 & 4.5 & 18 & & & \\
\hline Toplam & 8 & & & & & \\
\hline
\end{tabular}

Tablo 3. 5. incelendiğinde zencîr usûlünde sağ ve sol el tekniklerinde kullanılan ikâları (düzüm) yapabilme becerilerine ilişkin puanlarında istatistiksel açıdan belirgin fark yoktur. ( $U=8,000 ; p>0.05)$. Araştırmanın bu sürecinde sıra ortalamaları açısından her iki grubun eşit puanlara sahip oldukları görülmüştür. Diğer bir ifadeyle öğrencilerin sağ ve sol eldeki teknik davranışları yapabilme becerileri aynıdır.

$\mathrm{Bu}$ aşamada ise öğrencilerin zencîr usûlünde sağ ve sol el tekniklerinde kullanılan ikâları (düzüm) yapabilme becerileri ölçülmüştür. Elde edilen son test verileri tablo 3. 6.`da sunulmuştur.

Tablo 3.6. Zencîr usûlünde sağ ve sol el tekniklerinde kullanulan ikâlar (dü̃üm) yapabilme becerilerine yönelik. son test verileri

\begin{tabular}{lcccccc}
\hline Grup & $\mathbf{n}$ & S1ra Ortalamas1 & Sira Toplami & U & Z & p \\
\hline Deney & 4 & 6.5 & 26 & .000 & -2.428 & .015 \\
Kontrol & 4 & 2.5 & 10 & & & \\
\hline Toplam & 8 & & & & & \\
\hline
\end{tabular}

Tablo 3. 6. incelendiği zaman bir önceki aşamalardan farklı olarak öğrencilerin son test puanlarında istatistiksel olarak belirgin bir farka ulaşıldığı görülmüştür $(U=, 000 ; p<0.05)$. Bu fark araştırmanın amacını olumlu yönde etkileyen önemli bir faktördür. Bu sonuç şunu göstermektedir; deney grubunda konuya yönelik hazırlanan deneysel işlem süreci, öğrencilerin zencîr usûlünde sağ ve sol el tekniklerinde kullanılan ikâları (düzüm) yapabilme becerilerini önemli düzeyde artırmıştır.

\subsection{Alt Problem Doğrultusunda Bulgu Sonuçları}

$\mathrm{Bu}$ aşamada, öğrencilerin zencîr usûlündeki ikâları doğru tempo ile icrâ becerileri tespit edilerek ulaşılan sonuçlar tablo 3. 7.`e aktarılmışırır.

Tablo 3.7. Zencîr usûlündeki ikâlar doğru tempo ile icrâ becerilerine yönelik ön test verileri

\begin{tabular}{lcccccc}
\hline Grup & n & Sira Ortalaması & Sira Toplami & U & Z & p \\
\hline Deney & 4 & 3.5 & 14 & 14.000 & -1.528 & .127 \\
Kontrol & 4 & 3.5 & 22 & & & \\
\hline Toplam & 8 & & & & & \\
\hline
\end{tabular}

Tablo 3. 7.`de görüldüğü üzere katılımcıların puanlarında istatistiksel açıdan belirgin fark yoktur $(\mathrm{U}=4,000 ; \mathrm{p}>0.05)$. Benzer biçimde her iki grup arasında sıra ortalaması açısından yüksek bir sonuç görülse bile bu durumun istatistiksel yönden önemli bir fark oluşturmadığı anlaşılmaktadır

Tüm öğrencilerin son test verilerinde istatistiksel yönden ortaya farkın çıkı çıkmadı̆̆1 belirlenmiş ve bulgular Tablo 3. 8. `de sunulmuştur.

Tablo 3.8. Zencîr usûlündeki ikâlar doğru tempo ile icrâ becerilerine yönelik son test verileri

\begin{tabular}{lcccccc}
\hline Grup & n & Sira Ortalaması & Sira Toplamı & U & Z & p \\
\hline Deney & 4 & 6.5 & 26 & .000 & -2.494 & .013 \\
Kontrol & 4 & 2.5 & 10 & & & \\
\hline Toplam & 8 & & & & & \\
\hline
\end{tabular}


Tamay, S., \& Dönmez Devecioğlu, N. (2021). Türk mûsıkîsi usûl eğitiminde Dalcroze öğretim yöntemi ile zencîr usûlünün ögrenilebilirlik düzeyi. Journal of Human Sciences, 18 (2), 215-232. doi: 10.14687/ihs.v18i2.6101

Deneysel işlem sürecine yönelik uygulanan testlerin en son aşamasında tablo 3. 12.`den anlaşılacağı üzere öğrencilerin son test puanlarında istatistiksel açıdan belirgin fark yoktur $(\mathrm{U}=, 000$; p>0.05). Ulaşılan bu bulgu, araştırmanın amacını ve önemini olumlu yönde etkilemiş̧ir. Yapılan uygulamalar göstermiştir ki; deney grubu için hazırlanan çalışmalar, öğrencilerin zencîr usûlündeki ikâları doğru tempo ile icrâ becerilerini önemli ölçüde artırmıştır.

\subsection{Alt Problem Doğrultusunda Bulgu Sonuçları}

Bu aşamada, öğrencilerin zencîr usûlünde bestelenmiş bir esere eşlik etme becerileri sınanmış ve uygulanan Mann - Whitney U Testi sonucunda istatistiksel yönden belirgin bir farka ulaş1lp ulaşılmadığı belirlenmiştir. Elde edilen veriler Tablo 3. 9. `da sunulmuştur.

Tablo 3.9. Zencîr usûlünde bestelenmis bir esere eșlik etme becerilerine yönelik ön test verileri

\begin{tabular}{llccccc}
\hline Grup & n & Sira Ortalaması & Sira Toplami & U & Z & p \\
\hline Deney & 4 & 5 & 20 & \multirow{2}{*}{6.000} & -1.000 & .317 \\
Kontrol & 4 & 4 & 16 & & & \\
\hline Toplam & 8 & & & & & \\
\hline
\end{tabular}

Tablo 3. 9 incelendiği zaman her iki gurupta yer alan öğrencilerin zencîr usûlünde bestelenmiş bir esere eşlik etme becerilerine ilişkin puanlarında istatistiksel açıdan belirgin fark yoktur (U=6,000; $\mathrm{p}>0.05)$. Sira ortalamasinın kontrolünde deney grubu kontrol grubuna nazaran daha yüksek ortalamaya ulaştıkları anlaşılmaktadır. Bu durum, istatistiksel açıdan belirgin fark olarak değerlendirilmemektedir.

Öğrencilerin, zencîr usûlünde bestelenmiş bir esere eşlik etmelerini belirlemek amacıyla Mann - Whitney U Testi uygulanmıştır ve istatistiksel olarak belirgin bir farkın var olup olmadığ1 tespit edilmiştir. Veriler Tablo 3. 10.`da sunulmuştur.

Tablo 3.10. Zencîr usûlünde bestelenmis bir esere esslik etme becerilerine yönelik son test verileri

\begin{tabular}{llccccc}
\hline Grup & $\mathbf{n}$ & Sira Ortalamas1 & Sira Toplami & U & Z & p \\
\hline Deney & 4 & 5.25 & 21 & \multirow{2}{*}{5.000} & -.949 & \multirow{2}{*}{343} \\
Kontrol & 4 & 3.75 & 15 & & & \\
\hline Toplam & 8 & & & & &
\end{tabular}

Tablo 3. 10.`a göre kontrol ve deney grubu öğrencilerinin son test puanlarında istatistiksel açıdan belirgin fark yoktur ( $\mathrm{U}=5,000 ; \mathrm{p}>0.05)$. Sıra ortalamalar1, deney grubu kontrol grubuna nazaran eserleri doğru ritimle çalabilme becerilerinin yüksek bir ortalamaya sahip olduklarını göstermektedir. Bu sonucun, istatistiksel açıdan belirgin fark olmadığı anlaşılmaktadır. Bu durum göstermektedir ki, deney grubu için hazırlanan deneysel işlem süreci, katılımcıların zencîr usûlünde bestelenmiş bir esere eşlik etmeleri noktasında etkili olmuştur.

\subsection{Alt Problem Doğrultusunda Bulgu Sonuçları}

Öğrencilerin zencîr usûlünü bedensel hareketle icrâ etme becerilerinin ön test verileri Tablo 3. 11.`de sunulmuştur.

Tablo 3.11. Zencîr usûlünü bedensel hareketle icrâ etme becerilerine yönelike ön test verileri

\begin{tabular}{llccccc}
\hline Grup & $\mathbf{n}$ & Sira Ortalamasi & Sira Toplami & U & Z & p \\
\hline Deney & 4 & 4.5 & 18 & \multirow{2}{*}{8.000} & .000 & \multirow{2}{*}{1.000} \\
Kontrol & 4 & 4.5 & 18 & & & \\
\hline Toplam & 8 & & & & & \\
\hline
\end{tabular}


Tamay, S., \& Dönmez Devecioğlu, N. (2021). Türk mûsıkîsi usûl eğitiminde Dalcroze öğretim yöntemi ile zencîr usûlünün ögrenilebilirlik düzeyi. Journal of Human Sciences, 18 (2), 215-232. doi: 10.14687/jhs.v18i2.6101

Tablo 3. 11.'e verileri doğrultusunda her 2 grubun bedensel hareketle icra etmeleri noktasında belirgin fark tespit yoktur $(\mathrm{U}=8,000 ; \mathrm{p}>0.05)$. Sira ortalamaları ise her iki grubun eşit puana sahip olduklarını göstermektedir.

Gruplar arasında istatistiksel yönden belirgin bir farkın var olup olmadığı belirlenmiştir. Veriler Tablo 3. 12.'de sunulmuştur.

Tablo 3.12. Zencîr usülünü bedensel hareketle icrâ etme becerilerine yönelike son test verileri

\begin{tabular}{lcccccc}
\hline Grup & $\mathbf{n}$ & Sira Ortalaması & Sira Toplami & U & Z & p \\
\hline Deney & 4 & 6.38 & 25.5 & .000 & -2.381 & .017 \\
Kontrol & 4 & 2.63 & 10.5 &. & & \\
\hline Toplam & 8 & & & & & \\
\hline
\end{tabular}

Tablo 3. 12. incelendiği zaman her iki grupta yar alan öğrencilerin zencîr usûlünü bedensel hareketle icrâ etme becerilerine yönelik son test puanlarında istatistiksel açıdan önemli fark ortaya çıkmıştır ( $\mathrm{U}=, 000 ; \mathrm{p}<0.05)$. Bu veri doğrultusunda, deney grubu için uygulanan deneysel işlem etaplarının oldukça etkili olduğunu işaret etmektedir.

\section{SONUÇ, TARTIŞMA VE ÖNERİLER}

Denklik testi sonuçları genel olarak değerlendirildiğinde, son testlerin sonunda deney grubunun kontrol grubuna nazaran başarılı olması ve öğretim sisteminin düzenli biçimde uygulanması araştırmanın amacıyla örtüştüğunü göstermektedir. Grupların oluşumunda uygulanan denklik testi sonuçları doğrultusunda puan ortalaması eşitliği sağlanarak oluşturulmuştur. Her 2 grubun denklik testi puan ortalamas 320 olarak belirlenmiştir.

Puan değerlendirmesi "Performans Değerlendirme Ölçeği”" ele alınarak alanında iki uzman gözlemci tarafindan verilmiştir.

Bilim ve Sanat Merkezi öğrencilerini temel alan öğretim sistemi, öğrencilerin seviyelerine uygun olarak hazırlanmıştır. Özel yetenekli öğrencilerin seviyelerinden çok aşağıda bir eğitim öğretim tekniği ilerlemenin önündeki en büyük sorun olarak karşımıza çıkmaktadır. Bu sebeple plan ve program uygulamaları, öğrencilerin seviyelerine uygun olarak hazırlanmıştır.

Bilsem öğrencilerinin yaşıtlarına göre daha fazla bilgi edinebilme özelliği taşıması, araştırma üzerinde; daha az tekrara ve daha büyük kavramlar üzerinde yoğunlaşmaya imkân sağlamıştır. Bu çocukların normalden üç kat daha hızlı bir süreçte konuyu kavradıkları ve ilerledikleri unutulmayarak, yaşıtlarına göre uygun pek çok etkinliğin basit gelebileceği düşüncesi ön görülerek Tablo 2. 1.'de sunulan bir çalışma takvimi uygulanmıştır.

Öğrencilerin hızlı öğrenme becerilerinden dolayı deneysel çalışma yavaş ilerlememiş, sık tekrarlar yapılmamıştır. Bu nedenle öğrencilere daha güç ve fikir yürütmeye yönelten görevler sunulmuştur. $\mathrm{Bu}$ öğrencilere uygulanan plan ve program ezberlemenin ötesinde, edinilen bilgiyi disiplinler arası yaklaşımla işleme firsatı sağlamıştır.

Araştırmada; Özel yetenekli öğrenciler için düzenlenmiş olan öğretim sistemi, onların sahip oldukları yetenek alanlarına uygun bir şekilde oluşturulmuştur. Tüm öğrencilerin özellikleri dikkate alınarak ve bu doğrultuda öğretimin düzenlendiği uzaktan eğitim öğretim sistemi ile yetenek ayrımı gözetmeden tüm öğrencilere bu etkinlikten en üst düzeyde yararlanma imkânı elde etmiştir.

Zencîr usûlünün öğretiminde tümevarım yöntem biçimi kullanılmıştır.

Deneysel işlem sürecinde, Tanbûrî İzak’a ait zencîr usûlü ile bestelenen "beste-i zencîr - i zülfündür gönül ey dil - rübâ" (TRT repertuvar numarası: 1566) ve Hammâm - î zâde İsmâil Dede Efendi ye ait "ol mâh - i tâbı acep gösterir mi bana felek" (TRT repertuvar numarası: 8510) adlı eserlerin icrası öğrencilerin bu usûlü daha kolay benimsemesine olanak sağlamıştır.

Sonuç olarak; Dalcroze yaklaşımının, öğrenciler üzerinde dikkat, mükemmel duyuş, müziksel okuma ve yazma, müziksel hafiza geliştirme gibi yeteneklerin beyin firtınası yapılarak beden ile ilişkilendirilmesi, zencîr usûlünün öğreniminde etkili olduğu tespit edildi. 
Tamay, S., \& Dönmez Devecioğlu, N. (2021). Türk mûsıkîsi usûl eğitiminde Dalcroze öğretim yöntemi ile zencîr usûlünün ögrenilebilirlik düzeyi. Journal of Human Sciences, 18 (2), 215-232. doi: 10.14687/ihs.v18i2.6101

Araştırmayı destekleyen en önemli argümanlar, son test sonucunda elde edilen yüksek puanlardır. Son test aşamasından sonra deney grubunun kontrol grubuna nazaran istatiksel olarak daha yüksek başarı göstermesi, deneysel işlem sürecin olumlu yönde etkili olduğunu göstermektedir.

Araştırmanın 3 alt problemine ilişkin istatistiksel sonuçlarında anlamlı ve belirgin bir fark gözlemlenmemiştir. Ancak araştırmayı bir bütün halde düşündügümüzde bu müstakil bulgu sonuçlarının sonuca pek fazla etki etmediği görülmektedir.

$2 ` n c i$ alt probleme ilişkin (nota değer işaretlerinin konumlandırıldığ usûl çizgilerinin özelliklerini tanıyabilme becerileri) ön ve son test sonuçlarında anlamlı ve belirgin bir fark olmamıştır. Ancak bu alt problem müzikal ifadelerde bilişsel bölümü ifade ettiğinden bu sonucun olması pek de yadırganamaz.

3 ve 4 üncü alt probleme ilişkin (zencîr usûlündeki ikâları doğru tempo ile icrâ becerileri zencîr usûlünde bestelenmiş bir esere eşlik etme becerilerine yönelik ön test verileri) ön ve son test sonuçlarında da anlamlı ve belirgin fark olmamıştır. Bu kazanımların müstakil olarak Bilim ve Sanat Merkezi öğrencilerinin yapabilme durumundan kaynaklandığ1 ancak bir bütün olarak düşünüldüğünde de bazı aksaklıkları beraberinde getirebilmektedir.

Bilim ve Sanat Merkezi öğrencileri, özel yetenekli öğrencilerdir. Bu çalışmanın özel yetenekli olmayan öğrenciler bünyesinde uygulanmasında olumlu sonuçlar vermeme durumu da göz önüne alınmalıdır. Olası böyle bir durumda da deneysel işlem sürecinin uzatılarak veya yüz yüze eğitim biçiminde yapılarak bu eksiklik giderilebilir.

Benzeri çalışmaların artması, Bilim ve Sanat Merkezi'nde ve genel olarak eğitim - öğretim alanında verimli ve olumlu sonuçlar elde edilmesine katkı sağlayabilir.

\section{KAYNAKÇA}

Büyüköztürk, Ş. (2010). Sosyal bilimler için veri analiz̧i el kitabı (10. Baskı). Ankara: Pegem Akademi Yayincilik.

Büyüköztürk, Ş. (2014). Deneysel desenler (4. Baskı). Ankara: Pegem Akademi Yayıncilık.

Çakar, Ș. (1996). Türk mûsıkî́sinde usûl. (1. Baskı). İstanbul: Millî Eğitim Basımevi.

Çelak, İ. (2009). Şan ve koro eğitimi programlarnda uygulanan solfej eğitiminde tartım ögrretiminin yeri ve bir model önerisi. Yayımlanmamış doktora tezi. Ankara Üniversitesi Eğitim Bilimleri Enstitüsü, Ankara.

Çevik, D. B. (2007). Müzik öğretim yöntemlerinden, Orff müzik öğretisine genel bir bakıs. Balkesir Üniversitesi Fen Bilimleri Enstitüsü Dergisi. 9 (1), 95 - 100.

Gedikli, E. (2007). Mürik eğitimi. (2. Basım). Bursa: Ezgi Kitabevi.

Karaarslan, T. (2015). Issbirlikli ögrenmenin ilkokul 4. smaf mürik dersinde ögrrencilerin ritim becerileri ve ösyeterlilik algular üzerine etkileri. Yayımlanmamış yüksek lisans tezi. Dokuz Eylül Üniversitesi Eğitim Bilimleri Enstitüsü, İzmir.

Karahasan, T. H. (2003). Mandolin metodu. (1. Baskı). İstanbul: Alkım Yayınevi.

Öner, A. (2011). Geleneksel Türk müriğ öğlerinin flüt eğitiminde kullanlmasina yönelik bir model önerisi. Yayımlanmamış doktora tezi. İnönü Üniversitesi Eğitim Bilimleri Enstitüsü, Malatya.

Özcan, V. (2007). Orffögretisinin ve yaratıc dramanm uygulandiğ ve uygulanmadiğ okullarda ögrencilerin mü̈ile dersine olan tutumlarmm karşılaștırlması. Yayımlanmamış yüksek lisans tezi. Dokuz Eylül Üniversitesi Eğitim Bilimleri Enstitüsü, İzmir.

Özdemir Tuncer, D. (2012). Okul öncesi eğitiminde Dalcroze yaklaşımı. Yayımlanmamış doktora tezi. İstanbul Teknik Üniversitesi Sosyal Bilimler Enstitüsü, İstanbul.

Özkan, İ. H. (1998). Türk mûsıkîsi nazariyatı ve usûlleri kudüm velveleri. (5. Baskı). Ankara: Ötüken Neșriyat.

Peşinci, F. A. (2014). Kodaly yönteminin Saygun ve Bartok piyano repertuarna uygulanması. Yayımlanmamış yüksek lisans tezi. Haliç Üniversitesi Sosyal Bilimler Enstitüsü, İstanbul.

Tufan, S. (2011). Mü̈rik ögretmeni adaylarmm Dalcroze - Kodaly ve Orff yaklassmlaryla ilgili görüsleri ile bu yaklaşımlarm adaylarn ögretmenlik uygulamasina ilisksin tutumlarna olan etkisi. Yayımlanmamış yüksek lisans tezi. Marmara Üniversitesi Eğitim Bilimleri Enstitüsü, İstanbul.

Yay, O. (2010). Klasik Türk müriğinde süreş içerisinde kullanulan vurmal çalgilar ve kullanm yerleri. 
Tamay, S., \& Dönmez Devecioğlu, N. (2021). Türk mûsıkîsi usûl eğitiminde Dalcroze öğretim yöntemi ile zencîr usûlünün ögrenilebilirlik düzeyi. Journal of Human Sciences, 18 (2), 215-232. doi: 10.14687/ihs.v18i2.6101

Yayımlanmamış yüksek lisans tezi. Haliç Üniversitesi Sosyal Bilimler Enstitüsü, İstanbul.

Yıldırım, K. (1995). Kodaly yöntemi ile mü̃ile eğitimi. Yayımlanmamış yüksek lisans tezi. Dokuz Eylül Üniversitesi Sosyal Bilimler Enstitüsü, İzmir.

Yıldız, G. (2002). İlkögrretimde mürik ögretimi birinci kademe. (1. Baskı). Ankara: Anı Yayınc1lı.

\section{Extended English Summary}

\section{Purpose}

Human history takes shape on the experience of gains that are rising day by day and accumulated in each new day. Music has a multidisciplinary character with its qualitative and quantitative aspects accompanying human history, constantly changing with the development of societies. In this study, interdisciplinary method technique was used for the musical perception and learning of the Turkish musical "zencîr usûlü" with the Dalcroze teaching method in the education of special talented students. The implemented plan and program aims to provide the opportunity to process the acquired knowledge with an interdisciplinary approach beyond memorization. In this study, in which pre - test and post-test control group experimental design was used, it was determined that besides supporting the academic development of gifted students regarding their situation, when the correct performance assessment and evaluation methods and tools are used in the education of the individuals in question, it was determined that they could progress faster in their field of competence.

\section{Method}

The model of the research was formed by the pretest-posttest control group model. One of the main problems seen in experimental studies is the selection of subjects, and this is of great importance in test-based control group designs. This situation can be explained by the view that the differences after the experiment in the scores of the experimental and control groups belonging to the dependent variable may be due to the differences before the experiment. "However, it can be said that the pre-test - post-test control group design is a strong pattern that provides the researcher with a high statistical power in testing the effect of the experimental procedure on the dependent variable, allows the findings to be interpreted in the context of cause - effect and is frequently used in behavioral sciences." (Büyüköztürk, 2014, p.24).

The working group consists of specially talented music students $(n=8)$ from Akhisar Science and Art Center in the 2020-2021 academic year.

Experimental design with test-based control groups was used in the data collection tool. The levels of Akhisar Science and Art special talented music students were determined by equivalence test results. Performance Evaluation Scale was used in the pre-test post-test stages. Correlation coefficient values of the used scales were calculated as 0,92 . This data is a positive result indicator in line with the reliability of the study.

In the fall semester of the 2020-2021 Academic Year, the distance education education system music lesson was held in Akhisar Science and Art Center within the scope of the lesson topic titled "120 Time Zencîr Uslü".

In order to distribute the groups in a balanced way, the ten-question equivalence test was applied to the participants.

In this study, the problematic was examined over two groups. In order for the study to be carried out in a healthy way, it is primarily stipulated to apply the equivalence test. In order to form the groups, 10 multiple-choice tests on basic music writing and elements were applied in accordance with the curriculum gains applied in the 2019-2020 Academic Year Akhisar Science and Art Center.

Question papers were prepared in the name of the students in order to be able to answer the test. At the time of the application of the study, since distance education was implemented in 
Tamay, S., \& Dönmez Devecioğlu, N. (2021). Türk mûsıkîsi usûl eğitiminde Dalcroze öğretim yöntemi ile zencîr usûlünün öğrenilebilirlik düzeyi. Journal of Human Sciences, 18 (2), 215-232. doi: 10.14687/jhs.v18i2.6101

educational institutions affiliated to the Ministry of National Education, the questions were asked and answered in the digital environment via the Zoom application in the form of online questions and answers.

In this process, firstly, the pre-test phase was applied to the study group students. After the 8week experimental process, the questions used in the pre-test phase were applied in the post-test phase without any intervention.

In order to confirm the validity of the rubric in the tests, an expert opinion form with 10 items and 5 options for each item was arranged. In this arrangement, the questioning and supervision of the graded scoring key content (questions, answer options, implementation times and the technique of the scoring key) that will measure the compliance of the participants to the studies and their behaviors in the teaching system and test stages (pre-test-post-test) were observed.

In this direction, the views of two educator experts from the music departments of universities were taken and compared. The study reliability coefficient among the raters was found to be 0.86 . This result reveals that the reliability of the study is high.

Video recordings of the students with performance content from all stages were made, presented to music educators who are experts in their fields and evaluated. The data obtained were transferred to the "Statistical Package for the Social Sciences 20" (SPSS 20) package program.

\section{Results}

The Mann - Whitney U Test was applied to determine whether there is a statistically significant difference in the pre-test and post-test results of the usability study of the teaching approaches prepared with Dalcroze teaching method techniques in the Turkish musical method education of the experimental and control group students.

In the post-test results of the 1st sub problem, a statistically significant difference was found on the part of the experimental group. ( $U=, 000 ; p>0.05)$.

As a result of the post-test regarding the 2 nd sub-problem of the study, no statistically significant difference was found between the two groups. ( $U=6,000 ; p>0.05)$. However, considering the mean ranks in line with these results, it shows that the experimental group students are more successful than the control group students.

A statistically significant difference was found on the part of the experimental group as a result of the final test on the 3rd sub-problem. $(U=, 000 ; p>0.05)$.

When the post-test results of the 4th sub-problem were examined, a statistically significant difference was found in the experimental group. ( $\mathrm{U}=, 000 ; \mathrm{p}>0.05)$.

No significant difference was found between the two groups in the posttest results of the 5 th sub-problem. $(U=5,000 ; p>0.05)$. In line with this result, when the mean rank is taken into consideration, it shows that the experimental group students have a higher average than the control group students.

In the post-test results of the 6th sub-problem of the study, a statistically significant difference was found on the experimental group side. ( $\mathrm{U}=, 000 ; \mathrm{p}>0.05)$.

Especially after the final test results, the experimental group has more successful scores among the groups than the control group. This shows that the experimental process (teaching system) applied in line with this result has a positive effect. In the view of these results, it was determined that the use of the rhythm (zencîr usûl) by performing physical movements in accordance with the Dalcroze teaching method revealed the procedural expressions in Turkish music.

\section{Conclusion}

In the research; The education system for specially talented students has been created in accordance with their talent areas. With the distance education system, which takes into account the characteristics of all students and in this direction, all students have the opportunity to benefit from this activity at the highest level, regardless of their ability. 
During the experimental process, "beste-i zencîr - i zülfdür gönül ey dil - rübâ" (TRT repertoire number: 1566) and Hammâm - î zâde İsmâil Dede Efendi's "ol mâh - i tâb1 acep gösterir mi bana felek" (TRT repertoire number: 8510) enabled students to adopt this method more easily.

As a result; It was determined that the Dalcroze approach was effective in the learning of the "zencîr usûlü" style by brainstorming and associating skills such as attention, perfect hearing, musical reading and writing, musical memory development with the body.

The most important arguments supporting the research are the high scores obtained as a result of the post - test. The statistically higher success of the experimental group compared to the control group after the last test phase shows that the experimental process has a positive effect on the process.

Increasing similar studies can contribute to achieving efficient and positive results in the Science and Art Center and in education in general. 